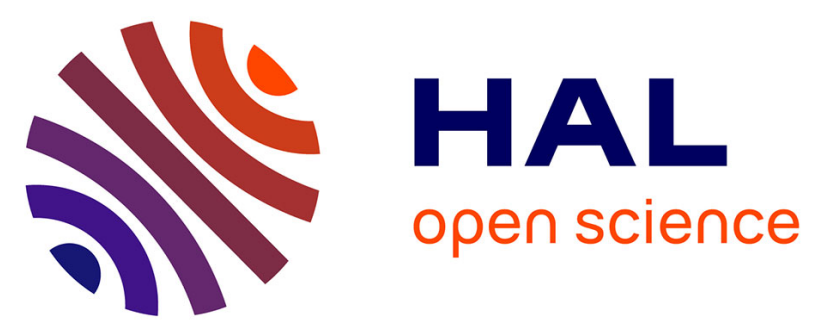

\title{
Bioactive properties of plant species ingested by chimpanzees (Pan troglodytes schweinfurthii) in the Kibale National Park, Uganda.
}

Sabrina Krief, M.A. Huffman, M. A. Sévenet, Claude Marcel Hladik, P.

Grellier, P. M. Loiseau, R.-W. Wrangham

\section{To cite this version:}

Sabrina Krief, M.A. Huffman, M. A. Sévenet, Claude Marcel Hladik, P. Grellier, et al.. Bioactive properties of plant species ingested by chimpanzees (Pan troglodytes schweinfurthii) in the Kibale National Park, Uganda.. American Journal of Primatology, 2006, 68, pp.51-71. hal-00589632

\section{HAL Id: hal-00589632 https://hal.science/hal-00589632}

Submitted on 29 Apr 2011

HAL is a multi-disciplinary open access archive for the deposit and dissemination of scientific research documents, whether they are published or not. The documents may come from teaching and research institutions in France or abroad, or from public or private research centers.
L'archive ouverte pluridisciplinaire HAL, est destinée au dépôt et à la diffusion de documents scientifiques de niveau recherche, publiés ou non, émanant des établissements d'enseignement et de recherche français ou étrangers, des laboratoires publics ou privés. 
Text published by: Krief, S., Huffman, M.A. Sévenet, T., C. Hladik, C.M., Greller, P., Loiseau, P.M. \& Wrangham, R.W. (2006) - Bioactive properties of plant species ingested by chimpanzees (Pan troglodytes schweinfurthii) in the Kibale National Park, Uganda. American Journal of Primatology, 68: 51-71.

\title{
Bioactive Properties of Plant species ingested by Chimpanzees (Pan troglodytes schweinfurthii)
}

\section{in the Kibale National Park, Uganda}

Sabrina Krief ${ }^{1,2^{*}}$, Michael A. Huffman ${ }^{3}$, Thierry Sévenet ${ }^{1}$, Claude Marcel Hladik², Philippe Grellier ${ }^{4}$, PHilippe M. Loiseau ${ }^{5}$ Richard W. Wrangham ${ }^{6}$

${ }^{I} I C S N$, CNRS, 1, av de la Terrasse, 91198 Gif-sur-Yvette Cedex, France

${ }^{2}$ Eco-Anthropologie et Ethnobiologie, USM 0104, Museum National d'Histoire Naturelle, 57 rue Cuvier, 75231 Paris Cedex 5, France

${ }^{3}$ Primate Research Institute, Kyoto University, 41-2 Kanrin, Inuyama, Aichi 484-8506 Japan

${ }^{4}$ USM 0504 Biologie fonctionnelle des protozoaires, Muséum National d'Histoire Naturelle, 61 rue Buffon, 75231 Paris Cedex 05, France

${ }^{5}$ Biologie et contrôle des organismes parasites, 92296 Chatenay-Malabry Cedex, France

${ }^{6}$ Peabody Museum, 11 Divinity Avenue, Cambridge MA 02138, USA

* Correspondence to: Sabrina Krief, Eco-anthropologie et Ethnobiologie, USM 0104, Museum National d'Histoire Naturelle, 57 rue Cuvier, 75231 Paris Cedex 5, France. E-mail:krief@mnhn.fr. Phone : 3314079 5337

\begin{abstract}
We examined the biological activities of a selected sample ( 84 crude extracts) of 24 species eaten by wild chimpanzees (Pan troglodytes schweinfurthii) in the Kibale National Park, western Uganda, to assess their potential chemotherapeutic values. Antibacterial, antimalarial, and/or antileishmania activities were observed in some crude extracts, and five of these extracts showed a significant cytotoxicity against human tumor cells. Active compounds isolated from three plant parts occasionally ingested by chimpanzees (Diospyros abyssinica (Ebenaceae) bark, Uvariopsis congensis (Annonaceae) leaves, and Trichilia rubescens (Meliaceae) leaves) showed highly significant medicinal properties. Two novel antiparasitic limonoids were isolated Trichilia rubescens and their molecular structures were determined. In addition to elucidating the natural equilibrium maintained between hosts and pathogens, our investigation of the diet of wild chimpanzees may serve as a guideline to discovering plants with bioactive properties that should be preserved from destruction because of their health maintenance value for great ape populations
\end{abstract}

\section{Key words:}

zoopharmacognosy; chimpanzee; chemical ecology; secondary compounds; bioassays 


\section{INTRODUCTION}

In order to fully appreciate and understand primate foraging behavior and plant selection criteria, recent studies have looked at the macronutrient and minerals content of items in the diet [e.g. ConklinBritain \& Wrangham, 1994; Conklin-Brittain et al., 1998; Chapman et al., 2003; Rode et al., 2003]. Behavioral, ecological and pharmacological studies have also shown the great ape diet to contain a variety of plant parts of no apparent nutritional significance that may be consumed because of their secondary compounds [e.g. Wrangham \& Waterman, 1983; Jisaka et al. 1992; Koshimizu et al., 1993; Huffman et al., 1998a; Wrangham et al., 1998]. The possibility that some of these dietary plants also have medicinal properties has been suggested [Ohigashi et al., 1994; Huffman et al., 1998a, b; Huffman, 2003]. Chemical investigations of the medicinal hypothesis have focused mainly on the consequences of two types of non-nutritional ingestion by chimpanzees, i.e. ingestion of items that appear to be of little or no nutritive significance. These are (1) swallowing whole leaves of various species, and (2) ingesting the bitter pith of Vernonia amygdalina [Wrangham \& Nishida, 1983; Huffman \& Seifu, 1989; Wrangham \& Goodall, 1989]. The antiparasitic properties of the plants ingested by chimpanzees in these cases were also investigated [Jisaka et al., 1992; Jisaka et al., 1993; Huffman et al., 1993; Koshimizu et al., 1994; Ohigashi et al., 1994; Huffman et al., 1996b;]. While leaf-swallowing has been convincingly implicated as an agent of parasite expulsion [Huffman et al., 1996; Huffman \& Caton, 2001] and might be involved in alleviating digestive pain caused by parasites [Wrangham, 1995], its known effects are due to physical rather than chemical causes [Huffman et al., 1996; 1997; Page et al., 1997; Huffman \& Caton, 2001]. Messner \& Wrangham [1996] for example tested the in vitro anthelmintic activity of Rubia cordifolia rough leaves but no significant activity was observed. Bitter-pith-chewing, on the other hand, has been shown to have potential pharmacological consequences based on chemical compounds apparently responsible for the control of nematode infections [Koshimizu et al., 1993; Huffman et al., 1993; Ohigashi et al., 1994; Huffman et al., 1996a]. Furthermore, it has been suggested that compounds found in the ordinary diet of animals may have important positive effects on health and may prevent risks of infection and illness [Janzen, 1978; Huffman, 1997; Huffman et al., 1998a]. This hypothesis is supported by the study of Vitazkova et al. [2001] where mice repeatedly sampled bitter substances as a likely feeding strategy for achieving chemoprophylaxis against parasite-related diseases. Mice infected by malaria parasites and mice that were not infected spontaneously ingested the amount of chloroquine sufficient to contain the infection, even if the solution was unpalatable. Even if naturally occurring plants with bitter taste are sometimes poisonous, by sampling a variety of bitter substances in small amounts, animals may reduce the likelihood of ingesting lethal doses and increase the chance of ingesting a plant with medicinal prophylactic value. We studied the chemistry of the plant diet of chimpanzees so as to assess its possible pharmacological value.

Our goal was to screen biological properties of plant species from Kibale National Park, Uganda that may be of benefit to the health of chimpanzees. In addition, this approach offers the opportunity to describe important secondary compounds in the chimpanzee diet, including isolation of any previously undescribed natural compounds. As part of our survey of secondary compounds in the diet of chimpanzees, species ingested by chimpanzees were investigated and different tissues (bark, leaves, fruits or flowers) were tested even if not consumed. This was done for three reasons. One reason for this is the necessity to fully understand the criteria of plant selection of Kanyawara chimpanzees, a second reason is to take into account the potential differences in consumption of plants according to study site [Goodall, 1986] and the use by other animal species, and a 
final reason is to provide a better knowledge of plant species, an important natural resource which should be preserved for the health of both local animals and humans. The use of plant products is today common to both traditional and western medicine. New approaches are needed in the search for drugs to combat widespread infectious diseases such as malaria, leishmania and cancer. Such a study also provides a database for researchers working on different primate species eating the same plant species and emphasizes the necessity of large-scale screening. Based on previous findings (Huffman et al., 1998a), in an attempt to highlight potentially the most biologically active plant parts in the diet of chimpanzees, those items ingested rarely, or only in small amounts, were collected. Another rational for focusing on rarely ingested items in the diet is the 'dose dependent' distinction made between poison and medicine. Our criteria of selection was used as a simple guideline, and is not intended to represent an absolute measure of a plant's medicinal value to chimpanzees. Plant materials collected were tested for their pharmacological properties against parasites, bacteria, and yeasts. In order to test the hypothesis of the potential effect of plant ingestion on health, we monitored chimpanzee health noninvasively by using feces and urine analysis, veterinary diagnosis and behavioral observations [Krief et al., 2005 , in press]. The levels of activity and the context of consumption may help to highlight different aspects of potential medicinal effects of the plants ingested.

\section{METHODS}

\section{Study site}

This study was conducted in the Kibale National Park, between December 2000 and March 2001 (dry season), and in October 2001 (rainy season). The park, located between $0^{\circ} 13$ 'to $0^{\circ} 41^{\prime} \mathrm{N}$ and $30^{\circ} 19^{\prime}$ to $30^{\circ} 22^{\prime} \mathrm{E}$, occupies $795 \mathrm{~km}{ }^{2}$ of mid-altitude moist forest, secondary forest, grassland, swamps and plantations of Eucalyptus and pines and it includes elements of lowland tropical rainforest, montane rainforest and mixed deciduous rainforest. The elevation is between 800 and $1500 \mathrm{~m}$, and the rainfall averages $1700 \mathrm{~mm}$ per year.

\section{Behavioral observations}

SK observed the habituated Kanyawara community of chimpanzees (Pan troglodytes schweinfurthii) including about 50 individuals, with 10 adult males and 16 adult females. We recorded feeding observations by 10-min focal-animal sessions and ad libitum observations during particular sequences related to possible medicative behaviour especially of sick chimpanzees and for ingestion of items rarely eaten and/or that appeared most likely non-nutritional. In total, 3864 focal sessions were collected. Health state was monitored daily with non-invasive methods [Krief et al., 2005 in press].

\section{Veterinary survey}

Veterinary work consisted of daily clinical observations (respiratory, digestive, reproductive, urinary functions, and locomotion). Intestinal parasite evaluation was carried out by examination of feces. When following the focal animal throughout the day, particular attention was paid to any abnormal behavioral activity, especially clear signs of potential illness such as decreased appetite, long and frequent resting, sneezing, coughing or intestinal disorder, as described by Huffman et al. [1997]. Whenever possible, feces were collected from all individuals clearly identified.

Fecal samples were inspected immediately after discharge to check for the presence of macroscopic parasites, then collected and stored individually in vials, a part being stored in formalin. Fresh samples were 
analyzed microscopically using the MacMaster flotation method, and a direct method to ascertain the load and species present was applied to the formalin samples, as described by Krief et al. [2003].

A total of 252 dung samples from identified chimpanzees were collected, including 187 samples collected during the dry season and 65 during the rainy season. These samples came from 38 individuals, mainly adults (127 samples from 18 females and 125 samples from 20 males).

\section{Plant collection}

Our plant collection was based on the observation that some types of food appeared more likely than others to have medicinal effects, i.e.: (1) bark, which appears to provide minimal nutritional gain and seems

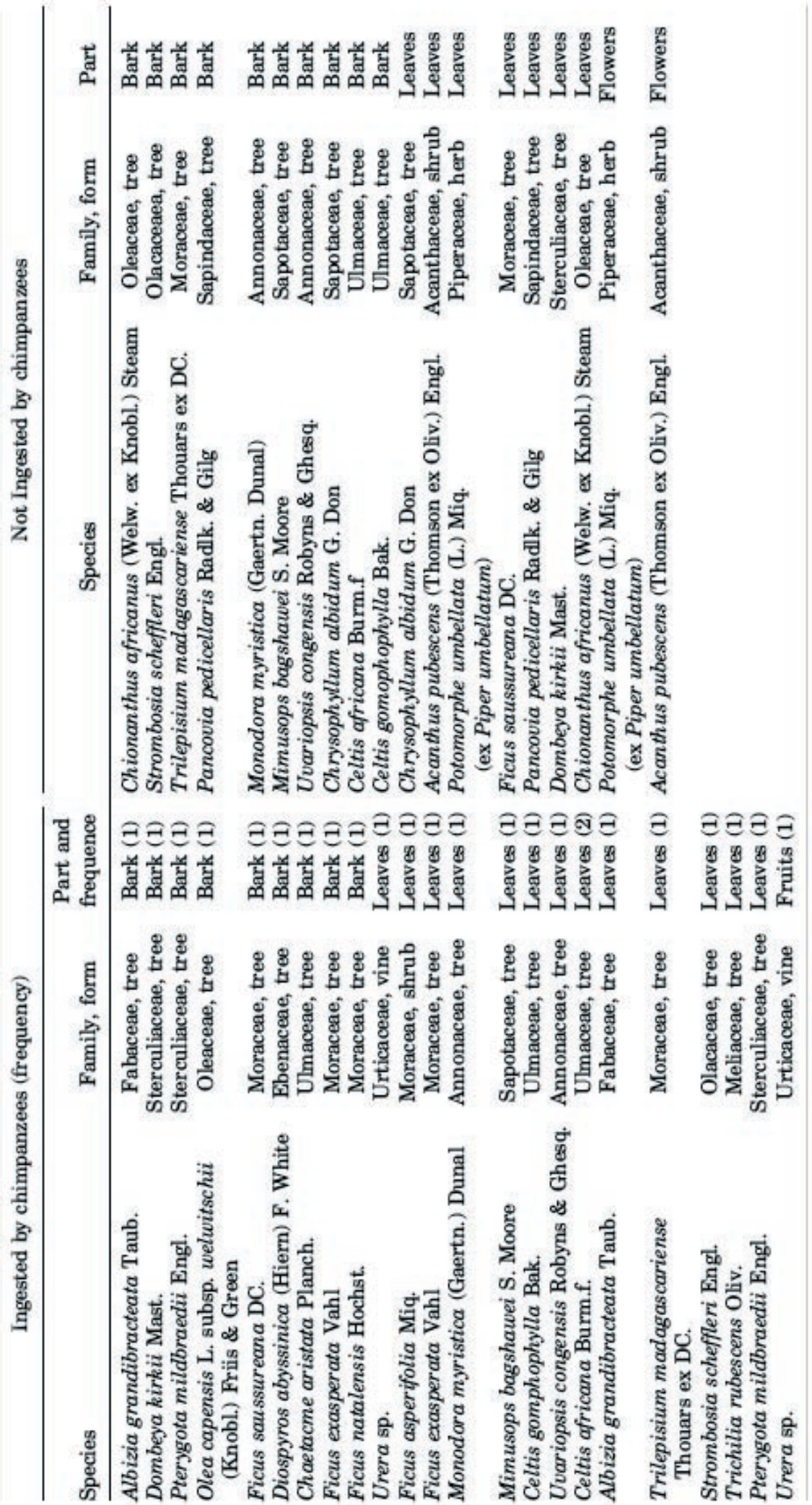


energetically costly to remove from the tree; (2) rough-surfaced leaves (e.g. Ficus exasperata and Ficus asperifolia) which could have physical properties important for parasite expulsion; (3) plants with spines like Chaetacme aristata or Acanthus pubescens, which are difficult to eat; and (4) urticant plants like Urera sp. Among the plant parts we collected that are eaten by chimpanzees, all but one (Celtis africana leaves) are consumed only infrequently and thus can not be considered as a major component of their nutritional intake according to long-term data (TABLE I). In addition to the plant parts specifically eaten by chimpanzees, we collected other parts from the same species. This was done for comparison and to increase our general knowledge of the entire plant's chemistry. Plant specimens were identified with the help of field assistants, then compared and identified in the herbarium of the Laboratoire de Phanérogamie at the Museum National d'Histoire Naturelle (Paris, France). Plant material was sheltered from the sun and air-dried in the field.

\section{Chemical analysis}

The air-dried finely powdered plant material was extracted three times consecutively with ethyl acetate and methanol heated at $40^{\circ} \mathrm{C}$ for three hours. 84 crude extracts were made from the different parts of 24 plant species from 13 botanical families. The extracted solutions were concentrated in vacuo providing crude extracts. Thin Layer Chromatography (TLC), column chromatography and High Performance Liquid Chromatography (HPLC) were used to fractionate bioactive extracts and to isolate active compounds. Spectroscopic analyses

$\left({ }^{1} \mathrm{H}-\mathrm{NMR},{ }^{13} \mathrm{C}-\mathrm{NMR}, \mathrm{LC}-\mathrm{MS}\right.$, EI-MS, IR and UV) were employed to determine the chemical structures.

\section{In vitro bioassays}

Dried extracts dissolved in DMSO (Dimethyl Sulfoxide) were assessed for in vitro activities against the following parasites Leishmania donovani, Trypanosoma brucei brucei, Plasmodium falciparum and a free-living worm Rhabditis pseudoelongata with almost the same sensibility to Ivermectin as a parasite worm. Antitumor activities were assayed by measuring the cytotoxicity against KB cells from human tumor tissue. Extracts were also tested against bacteria (Staphylococcus aureus, Escherichia coli) yeast and fungi (Candida tropicalis, Penicillium crustosum). All the tests were conducted in duplicate or triplicate, and means of the assays are presented in the following results. The results are expressed as the concentrations inhibiting parasite or cells growth by $50 \%$ ( $\mathrm{IC}_{50}$ ) or killing $50 \%$ of the population for worms $\mathrm{LD}_{50}$ (lethal dose $50 \%$ ).

The anti-trypanosomal screening was carried out according to the method described by Loiseau et al. [2000]. Trypanosoma brucei brucei GVR 35/Cl.2 bloodstream forms were used for in vitro screening. Leishmania donovani (MHOM/IN/80/DD8) promastigote forms were used for in vitro screening. The antileishmania screening was performed according to the method described by Mbongo et al. [1997].

Antimalarial activity was tested against intra-erythrocytic asexual forms of the human malaria parasite Plasmodium falciparum, following the method of Desjardin et al. [1979]. We prepared an asynchrone culture of parasites [Trager \& Jensen, 1976] with human serum containing parasitemia of $1 \%$ and a hematocrit of $2 \%$. For anthelmintic assay,_Rhabditis pseudoelongata were isolated from wild rabbit feces and maintained on sterilized rabbit feces. They were recuperated from a 10 days old culture by the Baerman method. Worms isolated were larvae I, II, III and IV stage and male and female adults. Two-hundred worms were deposited in each of the 24 wells of the plate. Extracts in DMSO were added and the wells were filled up to $500 \mu$ l with sterile water. Motile and non-motile worms were counted and compared with the control wells. Cytotoxicity assays were conducted on $\mathrm{KB}$ cell line. The $\mathrm{KB}$ cell line was derived from an epidermoid carcinoma in the mouth of 
an adult human [Eagle, 1955; Shoemaker et al., 1983]. A suspension of 75,000 cells in $2 \mathrm{ml}$ of 199/bicarbonate medium was deposited in every well. Two control tests with solvent and adriblastine $10^{-7} \mathrm{M}$ were prepared. Trays were incubated for 3 days. Two-hundred $\mu l$ of neutral red were added and trays were incubated one more night. The day after, suspension was removed and the cells were washed rapidly with PBS and $1 \mathrm{ml}$ of SDS was deposited in every well. The living cells incorporate neutral red, while the dead cells do not [Borenfreund \& Puerner, 1985]. Absorbance of neutral red was measured with a $540 \mathrm{~nm}$ filter. Antimicrobial assays against bacteria, yeast and fungi were conducted following two steps; antimicrobial screening and evaluation of the Minimum Inhibition Concentration (MIC). Disks were soaked with $500 \mu \mathrm{g}$ of extract in $20 \mu \mathrm{l}$ of methanol, dried and laid down in Petri boxes inundated with colonies in culture medium. They were incubated at $37^{\circ} \mathrm{C}$ for the bacteria and at $27^{\circ} \mathrm{C}$ for the fungi for 18 hours. The diameter of the inhibition zone was read. Bacteria used were Staphylococcus aureus ATCC 6538 (culture medium: Mueller-Hinton), Escherichia coli ATCC 8739 (culture medium Mueller-Hinton) and fungi were Candida tropicalis ATCC 66029 (culture medium: Sabouraud) and Penicillium crustosum LCP 75.3045 (culture medium: Malt Agar extract). Extracts selected by this method for their activities were tested in liquid medium for antimicrobial activity against Staphylococcus aureus to determine MIC. Other microbial targets did not exhibit significant activities. Extracts in DMSO and suspension of bacteria in exponential growth in Luria Bertoni medium $(0,2 \mathrm{~nm}<\mathrm{DO}<0,4 \mathrm{~nm})$ were deposited in 96 well trays. Control tests were performed using DMSO and bacterial suspension. Trays were incubated at $30^{\circ} \mathrm{C}$ and shacked at $250 \mathrm{RPM}$ for 18 hours. Absorbency at $620 \mathrm{~nm}$ was measured. The lowest concentration of test extracts in which no growth occurred was defined as MIC. The contents of the well were removed and cultured in Petri boxes using Mueller-Hinton medium to check the bactericidal or bacteriostatic activity. Growth of bacteria was examined after $48 \mathrm{~h}$ by visual inspection.

\section{Fractionation of bioactive extracts and isolation of pure products}

According to the TLC results, we selected appropriate solvents to fractionate the crude extracts that appeared to be the most active, with the following specific methods:

(1) The crude methanol extract of Diospyros abyssinica bark was chromatographed on silica gel with heptane-ethyl acetate. Fractionation was bioguided by activities on Leishmania donovani. The active fractions were purified by HPLC (Thermo-Hypersil 250x21.2 mm $5 \mu$ Kromasyl HS C18).

(2) Dried bark powder of Uvariopsis congensis was first defatted with heptane then extracted with ethyl acetate. Crude ethyl acetate extract was fractionated on silica gel with heptane-acetone. Column chromatography with isopropanol-dichloromethane and HPLC (Thermo-Hypersyl 250x21.2mm $5 \mu$ Kromasyl HS C18) on the more active fractions on KB cells were used to isolate compounds.

(3) Purification of the extract of the leaves of Uvariopsis congensis was performed by HPLC (ThermoHypersyl 250x21.2mm $5 \mu$ Kromasyl HS C18).

(4) The methanolic extract of the bark of Albizia grandibracteata was partitioned with butanol-water and the butanol fraction was washed with ether. Four fractions were separated with Sephadex LH 20.

(5) Crude ethyl acetate extract of leaves of Trichilia rubescens fractionation was bioguided by its antimalarial activity. The extract was chromatographed on silica gel with dichloromethane-methanol and the active fractions against $P$. falciparum were re-chromatographed with heptane-ethyl acetate. 


\section{RESULTS}

\section{Pharmacological properties of plant parts ingested by chimpanzees}

According to data that we reviewed from Chapman \& Hall (2003), natural pure products have been isolated from $30(25 \%)$ of the species eaten by chimpanzees in the Kibale Forest showing that there is still little known about the chemistry of plants from their diet. Moreover, those compounds are not always extracted from the part ingested by the chimpanzees.

Table II shows the most active extracts screened from a total sample of 84 plant parts collected from 24 species ingested by Kanyawara chimpanzees. During the 3864 focal-animal sessions collected in the present study, chimpanzees were feeding or foraging for $47 \%$ of the time. Among the 46 plant items consumed in the present study, two of them were previously known to have pharmacological properties i.e. Antiaris toxicaria pith and leaves from which latex is used as dart poison and Phytolacca dodecandra berries, which contain bioactive saponins. The present pharmacological assays revealed three bioactive items (Albizia grandibracteata bark, Trichilia rubescens leaves and Ficus exasperata stems bark) consumed during the present study whose activities are reported hereafter and in Table II. All of these five items were consumed during less than $0.5 \%$ of the feeding time during our study period.

Of the 84 items tested, $45 \%(n=38)$ were bark extracts. Bark extracts represent $63 \%$ of items exhibiting a significant activity in the assays conducted. The difference between the two proportions is significant (Fisher test $\mathrm{P}=0.04$ ), consistent with our hypothesis that bark consumption may often be a high source of pharmacological compounds. However besides rarely eaten plant parts exhibiting significant $\mathrm{IC}_{50}$ values, food plants with weaker $\mathrm{IC}_{50}$ values but consumed in larger quantities may also have an important long-term pharmacological effect.

Various different kinds of bioactivity were detected among the crude extracts investigated. Antiparasite activities were found for several plant extracts. Six crude extracts $(7 \%)$ displayed noticeable antimalarial activity, i.e. their $\mathrm{IC}_{50}$ values were below $10 \mu \mathrm{g} / \mathrm{ml}$. Three samples among those were extracted from plant parts eaten by chimpanzees. Ethyl acetate and methanol crude extracts of Trichilia rubescens leaves and the ethyl acetate crude extract of Diospyros abyssinica bark had a significant $\mathrm{IC}_{50}$ value against Plasmodium falciparum. The ethyl acetate crude extract of Diospyros abyssinica bark exhibited high anti-leishmania activity after $24 \mathrm{~h}$ and $72 \mathrm{~h}$ incubation time $\left(\mathrm{IC}_{50}=1 \mu \mathrm{g} / \mathrm{ml}\right)$. Ten crude extracts had a $\mathrm{LD}_{50}$ against Rhabditis pseudoelongata below $100 \mu \mathrm{g} / \mathrm{ml}$.

Antimicrobial activities against bacteria, yeast or fungi were investigated. An inhibition zone with a diameter of $12 \mathrm{~mm}$ or more was observed for 17 crude extracts and 11 of them were bactericidal against Staphylococcus aureus. The MIC was below $25 \mu \mathrm{g} / \mathrm{ml}$ for four crude extracts. Three crude extracts (bark of Mimusops bagshawei, Chrysophyllum albidum and Pancovia pedicellaris) had an inhibition diameter of $9 \mathrm{~mm}$ or more but less than $12 \mathrm{~mm}$ against Escherichia coli. No extracts exhibited any significant activity against Trypanosoma brucei brucei, Candida tropicalis or Penicillium crustosum. We noted that the methanol crude extract of Acanthus pubescens flowers, which are not eaten by Kanyawara chimpanzees but consumed by Sonso chimpanzees [Pebsworth et al. in press] showed important anthelmintic activity at a range of $25 \mu \mathrm{g} / \mathrm{ml}$ to $50 \mu \mathrm{g} / \mathrm{ml}$. Its ethyl acetate extract was bactericidal (antimicrobial screening with disks) and its MIC against S. aureus was $25 \mu \mathrm{g} / \mathrm{ml}$.

In vitro tests of the biological activity of six crude extracts showed more than $85 \%$ cytotoxic activity on human $\mathrm{KB}$ cells at $10 \mu \mathrm{g} / \mathrm{ml}$. Five crude extracts had an $\mathrm{IC}_{50}$ at or below $1 \mu \mathrm{g} / \mathrm{ml}$, i.e. methanol crude extracts of Uvariopsis congensis bark and leaves, Albizia grandibracteata bark and leaves, and ethyl acetate crude extract of Diospyros abyssinica bark.

Bioactivities-Krief et al. 
TABLE II. Biological activities of plants species ingested by chimpanzees in Kibale National Park, Uganda (IC50: inhibiting concentration 50\%, LD 50: lethal dose 50\%, in bold, most significant activities)

Biological activities in $\mu \mathrm{g} / \mathrm{ml}$

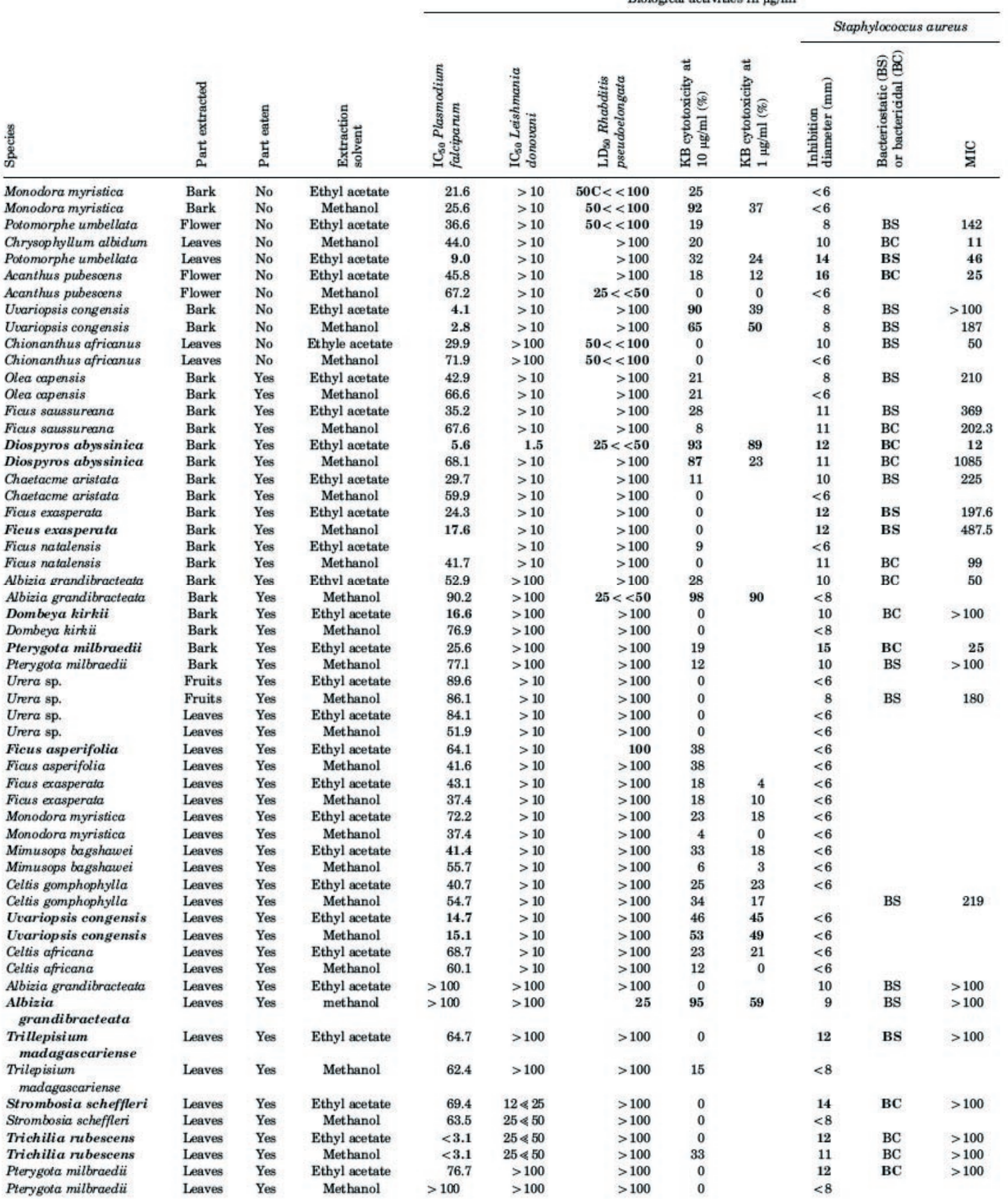


According to the results of biological screening, extracts from plant parts eaten by chimpanzees of Diospyros abyssinica, Albizia grandibracteata, Trichilia rubescens and Uvariopsis congensis, exhibited such high bioactivity that it leads us to strongly consider the chimpanzees selecting them had a criteria other than nutritive intake alone. Such items are rarely ingested by Kanyawara chimpanzees, as was the case for those plant foods with medicinal value for the treatment of parasite related maladies in Mahale chimpanzees [Huffman et al., 1998]. For these reasons, we decided to further investigate the chemical content of the extracts.

\section{Chemical investigations}

In order to isolate the bioactive constituents of plants from the chimpanzee diet, we focused our chemical analyses on the four plant species exhibiting the most significant biological properties; Diospyros abyssinica, Uvariopsis congensis, Albizia grandibracteata and Trichilia rubescens.

(1) Fractionation of Diospyros abyssinica bark (rarely consumed by chimpanzees) yielded isodiospyrin and diospyrin (Fig. 1), two bisnaphtoquinones identified by NMR, LCMS, UV and IR spectroscopy. Their IC 50 value against Leishmania donovani is $0.5 \mu \mathrm{M}$ ( $\mathrm{IC}_{50}$ L. donovani for the reference product: Pentamidine $\left.=7 \mu \mathrm{M}\right)$. Their activity against Plasmodium falciparum was weaker $\left(\mathrm{IC}_{50}=1.5 \mu \mathrm{M} ; \mathrm{IC}_{50}\right.$ chloroquine $\left.=0.1 \mu \mathrm{M}\right)$.

These quinones were previously isolated from other Diospyros species, and were known for their activities against protozoan parasites such as Leishmania donovani, Trypanosoma cruzi and Trypanosoma brucei brucei [Yardley et al., 1996]. They also showed inhibitory activities against murine tumors in vivo [Pal et al., 1996; Norhanom \& Hazra, 1997] and inhibition of blood platelet aggregation [Kuhe et al., 1998].

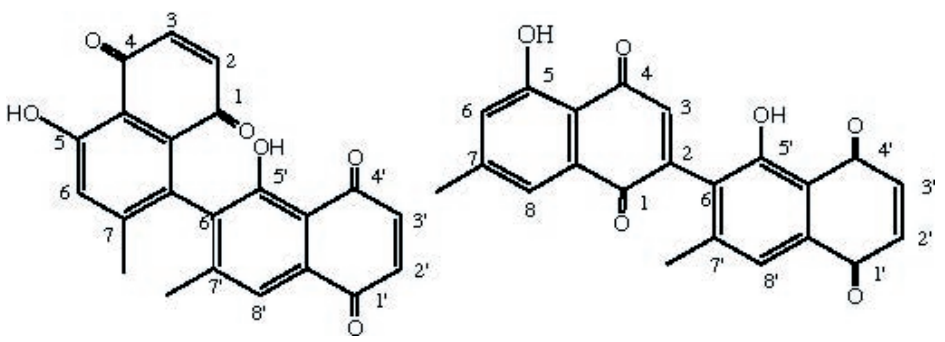

Fig.1 Two bioactive bisnaphtoquinones isolated from the bark of Diospyros abyssinica (Ebenaceae), eaten by the chimpanzees of Kanyawara, Kibale NationalPark, Uganda.

(2) The activities against Plasmodium falciparum and KB cells of the crude extract of Uvariopsis congensis were investigated. The crude extract of dried bark powder was purified. One of the compounds isolated was identified by NMR, LC-MS and EI-MS methods as cis-annonacin, an acetogenin (Fig. 2). This compound was the most common product from the leaves, sporadically eaten by chimpanzees. Its $\mathrm{IC}_{50}$ on $\mathrm{KB}$ cells is $0.24 \mu \mathrm{M}$ ( $\mathrm{IC}_{50}$ on $\mathrm{KB}$ cells for the reference product: Adriblastine $\left.=0.1 \mu \mathrm{M}\right)$. Gigantetrocine, another acetogenin potentially cytotoxic to tumoral cells $(2.2 \mu \mathrm{M})$ was isolated.

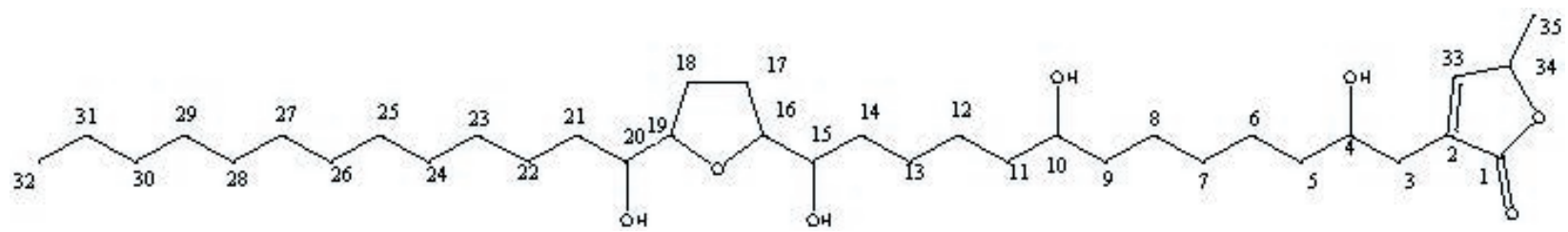

Fig.2 A bioactive acetogenin, the annonacin, isolated from the leaves of Uvariopsis congensis (Annonaceae) eaten by the chimpanzees of Kanyawara, Kibale National Park, Uganda 
(3) The methanol extract of Albizia grandibracteata bark (as eaten by OK 20 October 2001) had anthelmintic activity against Rhabditis pseudoelongata and was cytotoxic (90\% at $1 \mu \mathrm{g} / \mathrm{ml})$ to $\mathrm{KB}$ cells. A mixture of saponins was contained in the active fraction. Three products have been isolated and are structurally novel saponins [Krief et al., in prep.].

(4) After fractionation of the crude ethyl acetate extract of Trichilia rubescens leaves, the anti-malarial activity increased up to $4 \mathrm{ng} / \mathrm{ml}$. During this fractionation, novel limonoids, Trichirubines A and B, with high antimalarial activities were extracted and identified [Krief et al., 2004].
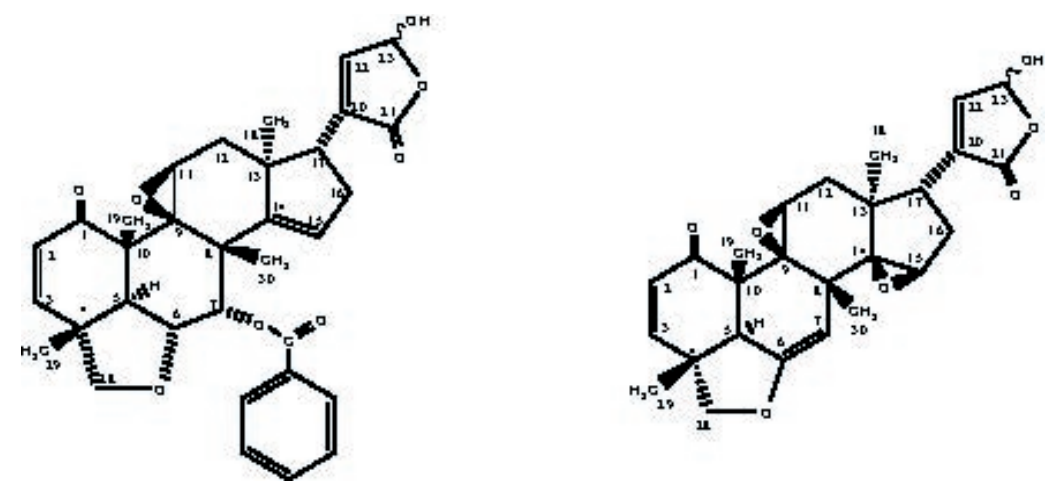

Fig.3 Antimalarial compounds, Trichirubines A and B, from the leaves of Trichilia rubescens (Meliaceae) ingested by the chimpanzees of Kanyawara, Kibale National Park, Uganda

\section{Chimpanzees ingestion of plants with bioactive compounds and their state of health}

Most of the chimpanzees monitored during the 4 months of this survey appeared to be in good health or, at least, improved quickly after small injuries or flu-like symptoms [Krief, 2003]. However, during the study period, at least 10 cases of patently ill chimpanzees were observed. Five cases were respiratory infections with nasal discharge, sneezing and coughing, including two severe cases with lethargy, dyspnea and anorexia. Two chimpanzees were detected suffering from gastrointestinal disorders. Bacterial infections were diagnosed in one wounded chimpanzee (LB) and in another individual (TU) suffering from tooth abscess. An old female (LP) with severe abdominal distension also had a left hand injury. The swollen hand was not used for tree climbing.

These wounded or sick chimpanzees were closely monitored in the field. Since the symptoms were totally absent after one week, we consider that all of them had recovered from their respective diseases. Their utilization of plants possibly with medicinal functions was examined in each instance (see following case studies).

Fecal samples showed the presence of parasites, with $93 \%$ and $95 \%$ prevalence for feces collected in the dry and the rainy season respectively. However, $96 \%$ of the samples had less than 1000 parasites per gram [Krief et al., 2003]. This corresponds to a low parasitic load for humans [Hercberg et al., 1986].

Among the 10 case studies of chimpanzee ill health presented in TABLE III, we selected two because of their particularly clear diagnosis and because it was possible to make sufficiently continuous observations to test the hypothesis of a potential effect of plants on health. They are as follows. 

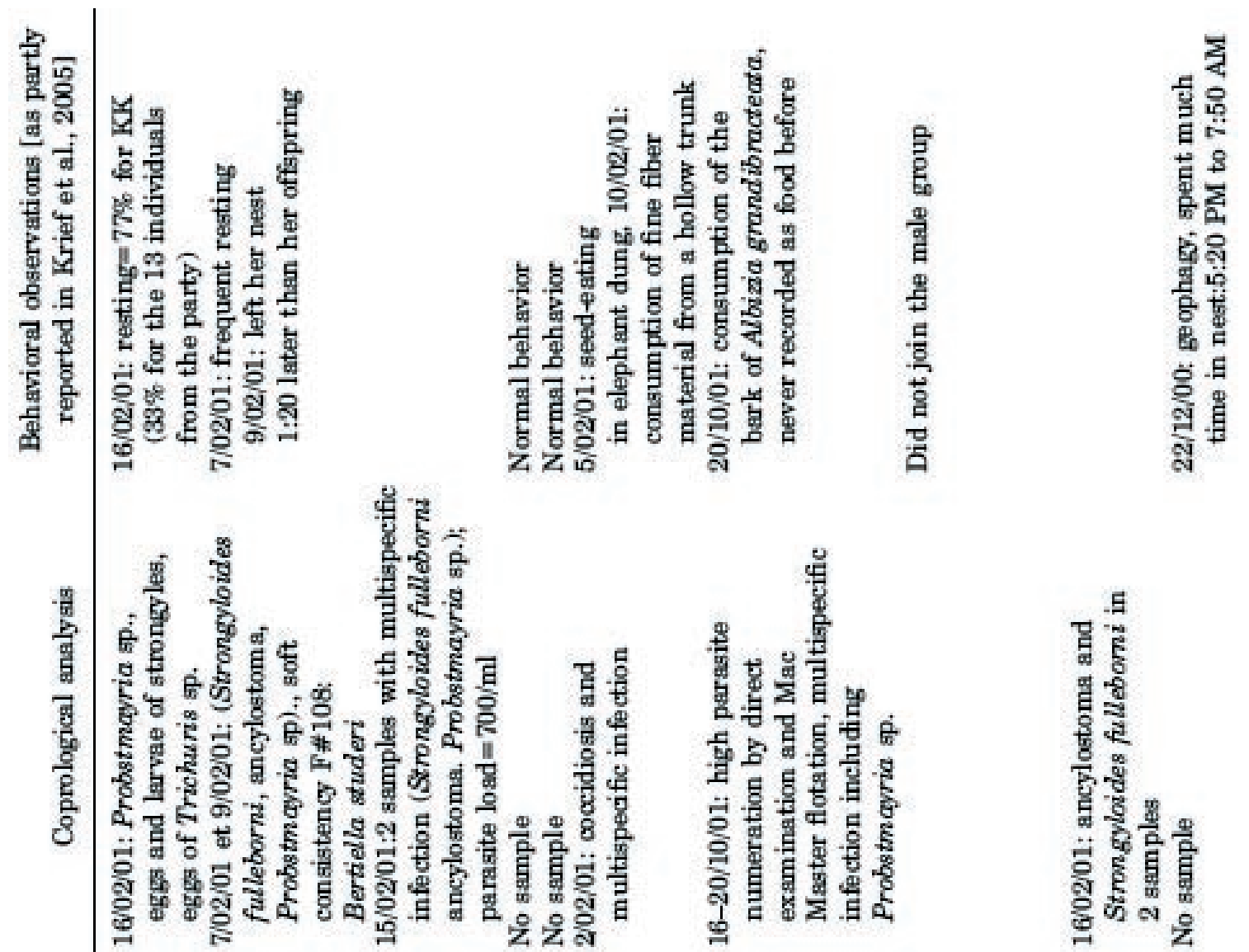

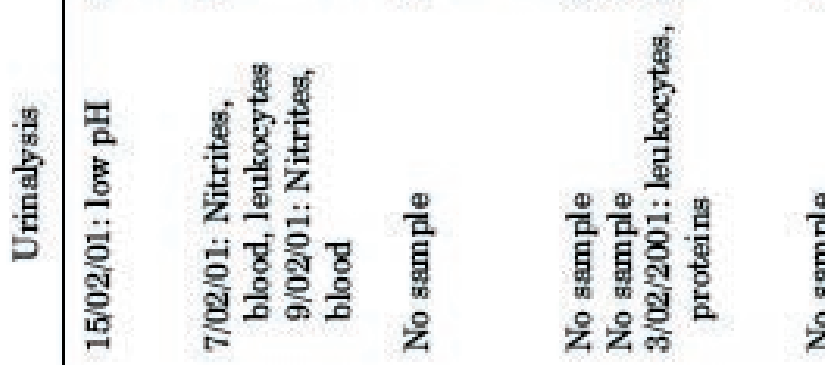

E

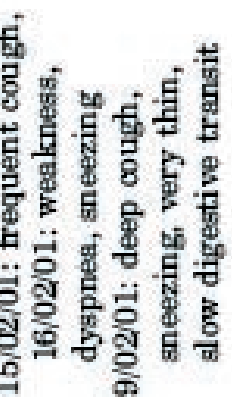
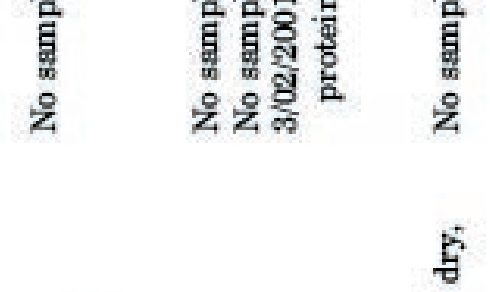

袞

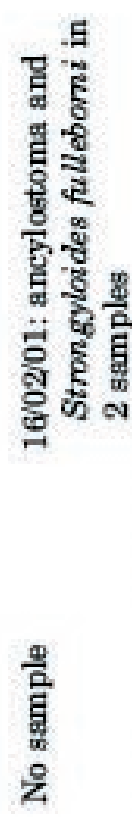

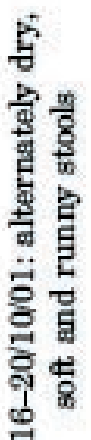

总

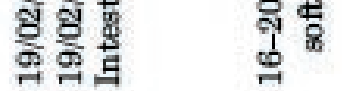
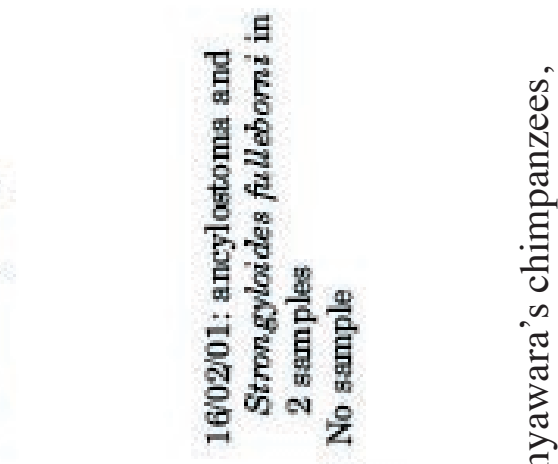

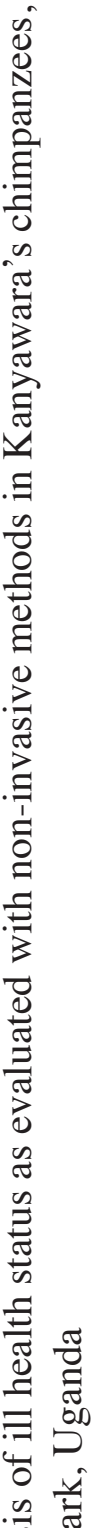

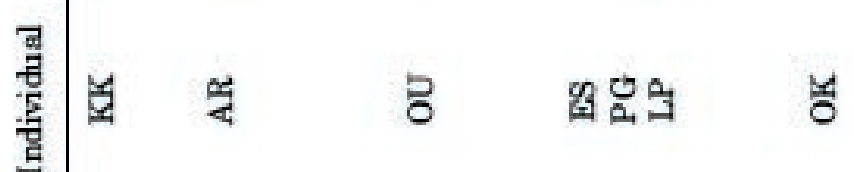

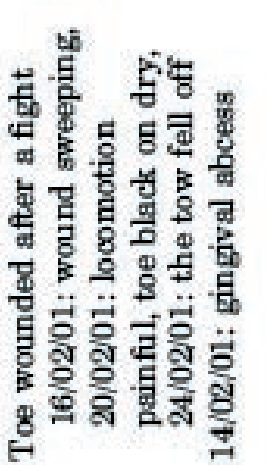

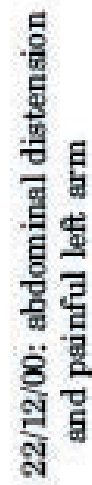

总

总

邹只急

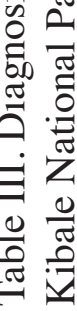

Bioactivities-Krief et al. 11 
(1) On 15 February 2001, a fight was observed between two adult males, YB and LB. YB bit LB's foot. The $5^{\text {th }}$ toe was severely cut, hanging from his foot by only a strip of skin. On 19 February, LB's locomotion appeared to be painful, and the following day, his toe was black and dry. The wound on the edge of his foot grew to be $1 \mathrm{~cm}$ deep, $4 \mathrm{~cm}$ wide. Nine days after the aggression, LB's toe fell off and the wound looked clean. LB's diet during this period contained 5 plants typically used in traditional medicine for wounds and other ailments in humans and domestic animals (TABLE IV). None of them were unusual dietary items, excepted the young leaves and stems of Ficus exasperata. Four chimpanzees from the same party were feeding on other items during his $F$. exasperata ingestion. We investigated the chemistry of three of these species to test whether or not they could have aided the recovery of LB's wound (results in TABLE III). Disks soaked with an ethyl acetate extract of Ficus exasperata bark are bacteriostatic, and leaves and stems of this species were eaten by the wounded chimpanzee.

TABLE IV. Ethnomedicinal information on plants ingested by a wounded chimpanzee (LB) in the Kibale National Park, Uganda (UPU : unknown part used, DRC : Democratic Republic of Congo, CAR : Central Africa Republic)

\begin{tabular}{|c|c|c|}
\hline $\begin{array}{l}\text { Species and part } \\
\text { ingested }\end{array}$ & $\begin{array}{l}\text { Date of } \\
\text { ingestion }\end{array}$ & $\begin{array}{l}\text { Use in traditional medicine for humans } \\
\text { and domestic animals }\end{array}$ \\
\hline $\begin{array}{l}\text { Acanthus pubescens } \\
\text { (stems) }\end{array}$ & $21 / 02 / 2001$ & $\begin{array}{l}\text { Burundi: stems against dermatosis, skin infections } \\
\text { and sterility of cattle (prelude website) } \\
\text { DRC: anti-inflammatory for limping (UPU) }\end{array}$ \\
\hline $\begin{array}{l}\text { Cordia africana } \\
\text { (fruits) }\end{array}$ & $\begin{array}{l}19,20,21 \\
24 / 02 / 2001\end{array}$ & $\begin{array}{l}\text { Burundi: anti-hemorrhage for humans (UPU) } \\
\text { (prelude website) }\end{array}$ \\
\hline Ficus sur (fruits) & $19 / 02 / 2001$ & $\begin{array}{l}\text { West Africa: immature fruits for reproductive } \\
\text { stimulation (prelude website) } \\
\text { Congo: piece of fruits on abscess, edema and } \\
\text { leprous ulcer [Bouquet, 1969] }\end{array}$ \\
\hline $\begin{array}{l}\text { Ficus natalensis } \\
\text { (fruits) }\end{array}$ & $16 / 02 / 2001$ & $\begin{array}{l}\text { South and East Africa: entire plant against } \\
\text { infectious veneral disease [Watt \& Breyer- } \\
\text { Brandwijk, 1962] }\end{array}$ \\
\hline $\begin{array}{l}\text { Ficus exasperata } \\
\quad \text { (leaves and stems) }\end{array}$ & $20 / 02 / 2001$ & $\begin{array}{l}\text { Congo leaves against edema, leprous ulcer } \\
\text { [Bouquet, 1969] and in application on } \\
\text { abscess (prelude website) } \\
\text { Sierra-Leone: leaves against dermatosis } \\
\text { (prelude website) } \\
\text { Congo: edema, abscess (UPU) (prelude website) } \\
\text { CAR: dermatosis (UPU) (prelude website) }\end{array}$ \\
\hline
\end{tabular}

(2) Starting about 16 October 2001, OK, a 6-year-old female, suffered from an intestinal disorder, evidenced by her producing alternately dry, soft and diarrheic stools. Fecal analysis revealed a high load of parasitic infection (strongyle species and Probstmayria gombensis) [Krief et al., 2003]. We observed OK eating Albizia grandibracteata bark at 9:42 on 20 October 2001. This was the first recorded time since the observations began in Kanyawara in 1987 that a chimpanzee had been seen to consume the bark of this species, though they have occasionally been observed eating its leaves. OK was the only one of the group to eat the bark. She ate it for 3 minutes while her mother and siblings were waiting for her. Feces collected two days after OK's ingestion of A. grandibracteata bark (October 22) had a normal consistency and the parasitic load was nil. 
Albizia grandibracteata bark is traditionally ingested as a medicine in Uganda and in Democratic Republic of Congo (DRC) against intestinal parasites and bloat [Heine \& Konig, 1988; Defour 1994]. This observation raises the possibility that OK's bark-eating was responsible for reducing the high parasite load and digestive symptoms seen since October 16.

\section{Regular presence of bioactive compounds in the diet}

Among unusual behaviors, we have observed that Kanyawara chimpanzees feed occasionally on Trichilia rubescens leaves. Such consumption bouts were short (from 1 to 21 minutes for our 21 observations, mean: 5 minutes) and infrequent (chimpanzees were observed to ingest these plant species from from 0 to 4 times per month across the 8 months of observation). Only a few leaves were eaten each time (ca. 7/ minute). This plant generally grows in a cluster so that leaves would be available for several chimpanzees. For each observation made, usually only one chimpanzee, rarely more, ate this item while in a group of 2 - 28 individuals. On two occasions, chimpanzees were observed ingesting 100 leaves or more at a time. In one case (11/06/2003), a wounded chimpanzee (AJ) consumed more than 100 leaves from 7:37 to 7:58 in the morning. Twelve minutes later, ST was observed feeding on Trichilia rubescens leaves (about 20). ST was observed 4 weeks later ingesting around 100 leaves without any observable or measurable symptoms. He was observed by LK, who was tasting a few leaves of the item. In one case, one individual (MS, 12/22/2003) was ingesting many leaves (60), observed by 3 individuals (BB, ST, TU) who did not consume the item. On $25^{\text {th }}$ March 2004, UM changed her travel route to consume a few leaves of this plant. Two minutes later, MS consumed 17 leaves. During the 8-month study period, three individuals were observed to ingest the plants on multiple occasions (MS: 3 times, AJ: 3 times, ST: twice). In each case the chimpanzee left the Trichilia shrub before having eaten all the leaves of the tree, except AJ who consumed leaves from 2 trees on the $6^{\text {th }}$ November 2003. These observations lead us to strongly suggest that chimpanzees eating Trichilia rubescens leaves may provide benefits other than nutritional as usually only small amount are consumed. Significant anti-malarial activities on the human protozoan parasite, Plasmodium falciparum, have been demonstrated for the crude extracts and two novel limonoids having a $\mathrm{CI}_{50}$ roughly equivalent to chloroquine have been isolated [Krief et al. 2004]. The human parasite is very similar to P. reichenowi, which occurs in west, central and east tropical Africa and affects gorillas and chimpanzees [Töft, 1986]. The several species of Plasmodium affecting great apes are generally considered as mildly pathogenic but few details have been reported in wild individuals [Töft, 1986]. No symptom that might be related to malaria were detected among chimpanzees in the present study. More accurate diagnosis is needed for detecting discrete symptoms. In one case, a larger amount was consumed by a wounded chimpanzee. In addition, Trichilia rubescens is easily confused with a closely related species, T. dregeana. Thus, Trichilia rubescens was previously identified as T. dregeana in Kibale National Park. Accordingly, it is noteworthy that Trichilia dregeana bark is used in traditional Zulu medicine to treat headaches or inflammatory diseases [Jäger et al., 1996]. Among 39 ethanolic plant extracts tested by Jäger et al. [1996], Trichilia dregeana showed high inhibitory activity for prostaglandin-synthesis. Prostaglandins are involved in the process of inflammation and are responsible for the feeling of pain. Such properties may have benefited the wounded chimpanzee, the pain felt by the chimpanzee being related to the increased amount consumed of a plant with analgesic effect. 


\section{DISCUSSION}

Results of the biological screening of plant parts eaten by chimpanzees demonstrated that some items ingested only rarely possess very significant pharmacological properties. This suggests that there may be motivational factors additional to nutritional value for choosing certain food items. Other plant parts exhibited weaker effects, which may act by cumulative effect or repeated ingestion. As suggested by Lozano [1998], there may be two aspects of self-medicative behavior, i.e. preventive and therapeutic. Without passing judgment here on whether the ingestion of some plants with a preventative function are conscious acts, it seems clear to us that the consumption of some plants with minimal nutritional benefits taken at low levels in the regular diet by individuals may act to prevent the risk of parasitism or infection and maintain a low level of pathogens. This study provides further new evidence that chimpanzees forage on some plants also used in human and veterinary traditional medicine [Huffman et al., 1996a; 1998a]. Among the 117 plant species known to be ingested by chimpanzees in the Kibale Forest from long-term records, at least 27 (23\%) are used in traditional African medicine according to published references and data available on websites [review in Krief, 2003; Krief et al. in prep.]. Even though the plant parts used by healers is often not included in the descriptions of the preparation, we found uses in traditional medicine for 35 of the 163 parts ingested by chimpanzees in Kanyawara. While a larger sample set including plants regularly eaten is necessary to demonstrate a correlation between the rate of consumption and bioactivities of the plant species, we do not believe that every species chimpanzees ingest has some kind of biologically active property. Cases of Albizia grandibracteata consumption related to intestinal disorder and increase of Trichilia rubescens consumption by a wounded chimpanzee provide evidence that ingestion of plants with medicinal properties is not just a random event and very well may be driven by a desire for certain secondary plant compounds. In the future, other properties such as anti-inflammatory activity would be interesting to screen.

The non-invasive health monitoring used during this study is a viable way to test the hypothesis of a regulation process induced by plant antiparasitic activities or immunostimulating properties of natural compounds. Thus, four points are consistent with the hypothesis that elements of the chimpanzees' diet can contribute to reducing the effect that parasites and microbes have on their health : (1) Some items ingested by chimpanzees are also common to traditional African medicine, (2) Chimpanzees showed a relatively low parasite load, (3) Most of the Kanyawara chimpanzees were in relatively good health as evaluated by urinalysis, fecal analysis and veterinary observations [Krief, 2003], (4) The results of biological property screening were confirmed by the isolation of pure bioactive compounds. It would be interesting to conduct similar studies on other primate species in the region.

The related observations of ill or wounded chimpanzees were consistent with the hypothesis that they benefited from the use of some plants with bioactive properties. Such plants are also used by the local population to treat similar symptoms [sic. Huffman \& Wrangham, 1994; Huffman et al., 1996; Huffman et al. 1998b]. For example, the diet of LB, when he was wounded, contained Ficus exasperata stems and leaves. Bark of stems have antibacterial properties and leaves are used in Africa to cure cutaneous infections and to relieve pain in humans and livestock [Bouquet, 1969]. Leaves of Ficus exasperata have also been prescribed as an anti-ulcer remedy; and a study on rats revealed that the extract of these leaves shows significant antiulcerogenic properties [Akah et al., 1998]. In addition, F. exasperata (parts tested not described) has already shown antitumor activities and remarkable inhibition of trypsin activity [Koshimizu et al., 1993]. These points 
suggest to us that LB's health could have been improved by the inclusion in his diet of some of these plants containing bioactive compounds.

The unusual feeding behavior on Trichilia rubescens leaves led us to the discovery of its interesting antimalarial activity. No symptom related to an infectious disease such as malaria was detected in chimpanzees ingesting this item, but malaria in apes is known to be sub-clinical or mildly pathogenic. Nevertheless, when coupled with other diseases, malaria may become deleterious [Skinner and Hopword, 2004]. Malaria was examined as the cause of linear enamel hypoplasia in apes by Skinner et al. [1995] and Guatelli-Steinberg and Skinner [2000]. In a recent survey on the prevalence of malaria in wild born, ex-captive Bornean orangutans, M.J. Reid and colleagues (pers. comm.) found that more than $25 \%$ of the individuals tested were infected by a Plasmodium parasite. Such clues suggest that pathogen pressure may be reduced by the ingestion of certain plants. This hypothesis was most clearly implied in the case when OK ate bark of Albizia grandibracteata while suffering from intestinal upset and had a heavy parasitic load. This unusual dietary item apparently increased OK's intake of compounds that were bioactive against helminths, because we found that A. grandibracteata bark contained bioactive saponins. Subsequently, OK's condition improved, and fecal examination confirmed reduced parasitism in vivo. These observations conform to the apparent importance of Albizia grandibracteata bark as a traditional medicine.

While OK's case suggests that her diet was effectively medicinal, further work will be required to prove it. First, chemical extractions with methanol or ethyl acetate solvents exclude the digestion process from pharmacological testing. Second, detoxification mechanisms could interfere with potential medicinal properties. Third, we need to quantify the amount of each plant consumed to estimate what bioactivity level may be expected in the chimpanzee's body. As proposed by Huffman [2003], the next step will be to conduct in vivo tests to determine efficiency of different plants parts in suppressing different pathogens relevant to chimpanzees.

According to the results of our in vitro tests, several plant species ingested by chimpanzees are active against human pathogens. Some of these agents, such as Staphylococcus aureus or Escherichia coli, can affect both humans and chimpanzees. In such instances the observation of chimpanzees choosing bioactive plant products supports the self-medication hypothesis. However, additional tests are needed for pathogens specific to chimpanzees, in spite of the phylogenetic proximity. Finally, even if medicinal activity is supported by further data, we acknowledge that in the case of plant parts that provide nutrients and minerals, it is difficult to assess the relative importance of nutritional signals, versus cues of bioactivity or painkilling, as influences on chimpanzee food choice.

In conclusion, this study shows that the chimpanzee diet includes compounds likely to offer medicinal benefits, including reducing the level of pathogens and keeping chimpanzee health problems to a sub-clinical level. Among the implications of the survey of chimpanzee diet, feeding behavior and health may lead to finding new natural products with potential medicinal properties for human beings. Such a diet may allow chimpanzees to maintain a good state of health and to prevent illness while avoiding potential toxicity and resistance induced by repeated consumption. Some plants with stronger biological properties are consumed in small quantities and only on rare occasions and thus are likely of curative value. Between these two mechanisms, we should consider that health is a continuum and the positive feedback of a medicinal substance may act during the sampling of the regular diet by an individual feeling weak discomfort. Therapeutic medication may also be learned individually and food aversion may be attenuated by observation of conspecifics feeding on this item. 
At a conference at the Max Planck Institute in Leipzig in 2004, where the network GAHMU (Great Apes Health Monitoring Unit) was created, disease was considered as the third major threat for great ape populations today. Habitat destruction, caused by opening roads into the forest, has a major impact not only by facilitating poaching and the bushmeat trade but also by enhancing the potential for pathogen introduction and transmission. Environmental disruption may change the balance between host and pathogens by depriving animals of important plants that provide both essential nutrients affecting immunologic status and secondary compounds that might help to fight against diseases. The effect on animals' health from deprivation of the diversity of secondary compounds is today probably underestimated because the actual medicinal value of plants is still unknown in most of the habitat of primates. Such a pharmacological approach to the study of their diet might also be a valuable new tool for primate conservation.

\section{ACKNOWLEDGMENTS}

We are grateful to the Government of Uganda for permission to work in the Kibale National Park. Facilities were provided by Makerere University Biological Field Station and we are thankful to J. Kasenene and G. Isabirye-Basuta for their collaboration in the fieldwork. Acknowledgements for funding are due to Centre National de la Recherche Scientifique and Museum National d'Histoire Naturelle, France. We are indebted to L. Allorge and A. Hladik for their help in identification of plant specimen. S.K. is also thankful to M.

Labaied, V. Bultel and C. Bories for their assistance in the activity tests and to members of the Institut de Chimie des Substances Naturelles de Gif-sur-Yvette for their valuable cooperation in the chemical work. J.M. Krief and F. Mugurusi provide helpful help and contribute to the data collection, we warmly thank them. For their invaluable assistance in the fieldwork, we express our sincere gratitude to K. Duffy, K. Pieta, the late D. Muhangyi, C. Katongole, C. Muruuli, P. Tuhairwe, J. Barwogeza, M. Musana. We are indebted to the anonymous reviewers who provide valuable comments to improve this manuscript.

\section{REFERENCES}

Akah PA, Orisakwe OE, Gamaniel, KS, Shittu, A. 1998. Evaluation of Nigerian traditional medicines:II effects of some Nigerian folk remedies on peptic ulcer. J Ethnopharmacol 62:123-127

Alados CL, Huffman MA. 2000. Fractal long range correlations in behavioural sequences of wild chimpanzees: a non-invasive analytical tool for the evaluation of health. Ethology 106:105-116.

Borenfreund E, Puerner JA. 1985. Toxicity determined in vitro by morphological alteration and neutral red absorption. Toxicol Lett 24:119-124.

Bouquet A. 1969. Féticheurs et médecines traditionnelles du Congo (Brazzaville). Mémoire O.R.S.T.O.M.

Chapman CA, Chapman LJ, Rode KD, Hauch EM and McDowel LR. 2003. Variation in the nutritional value of primate foods: among trees, time periods and areas. Int J Primatol 24: 317-333.

Chapman \& Hall. 2003. Dictionary of natural products on CD-ROM. Version 11:2. CRC PressUK.

Conklin-Brittain NL, Wrangham RW (1994). The values of figs to a hind-gut fermenting frugivore : a nutritional analysis. Biochem Syst Ecol 22: 137-151.

Conklin-Brittain NL, Wrangham RW, Hunt KD (1998). Dietetary response of chimpanzees and Cercopithecines to seasonal variation in fruit abundance. II. Macronutrients. Int J Primatol 19:971-998.

Defour G.1994. Plantes médicinales traditionnelles au Kivu (République du Zaïre). Documentation du SousRéseau PRÉLUDE. 
Desjardin RE, Canfield C-J, Haynes JD, Chulay JD. 1979. Quantitative assessment of antimalarial activity in vitro by a semi-automated microdilution technique. Antimicrob Agents Chemother 16:710-718.

Dupain J, Van Elsacker L, Nell C, Garcia P, Ponce F, Huffman MA. 2002 New evidence for leaf swallowing and Oesophagostomum infection in Bonobos (Pan paniscus). Int J Primatol 23:1053-1062.

Eagle H. 1955. Propagation in a fluid medium of a human epidermoid carcinoma, strain KB (21811). P.S.E.B.M. 89:362-364.

Guatelli-Steinberg D, Skinner, MF. 2000. Prevalence and etiology of linear enaml hypoplasia in monkeys and Apes from Asia and Africa. Folia Primatol 71:115-132.

Heine B, König C. 1988. Plant concepts and plant use. An ethnobotanical survey of the semi-arid and arid lands of East Africa. Part 2: plants of the So (Uganda). Cologne development Studies Verlag Breitenbach Publishers. Saarbrücken. Fort Lauderdale.

Hercberg S, Chauliac M, Galan P, Devanlay M, Zohoun I, Agboton Y, Soustre Y, Bories C, Christides J-P, Potier de Courcy G, Masse-Raimbault AM, Dupin H. 1986. Relationship between anaemia, iron and folacin deficiency, haemoglobinopathies and parasitic infection. Human Nutrition : Clinical Nutrition 40C: 371-379.

Huffman MA. 1997. Current evidence for self-medication in primates: a multidisciplinary perspective. Yearb Phys Anthropol 40:171-200.

Huffman MA. 2003. Animal self-medication and ethnomedicine: exploration and exploitation of the medicinal properties of plants. Proceeding of the Nutritional Society (February issue).

Huffman MA, Seifu M. 1989. Observations of illness and consumption of a possibly medicinal plant Vernonia amygdalina (Del.), by a wild chimpanzee in the Mahale Mountains National Park, Tanzania. Primates 30:51-63.

Huffman MA, Gotoh S, Izutsu D, Koshimizu K, Kalunde MS. 1993. Further observations on the use of medicinal plant, Vernonia amygdalina (Del) by a wild chimpanzee, its possible affect on parasite load, and its phytochemistry. Afr Stud Monogr 14:227-240

Huffman MA, Wrangham RW. 1994. Diversity of medicinal plants use by chimpanzees in the wild. In: Wrangham RW, McGrew WC, de Wall FB, Heltne, PG, editors Chimpanzee cultures. Cambridge, MA:Harvard p 129-148.

Huffman MA, Koshimizu K, Ohigashi H.1996a. Ethnobotany and zoopharmacognosy of Vernonia amygdalina, a medicinal plant used by humans and chimpanzees. In: Caligari PDS, Hind DJN, editors. Compositae: Biology \& Utilization Vol 2., Kew: The Royal Botanical Gardens. p 351-360.

Huffman MA, Page JE, Sukhdeo MVK, Gotoh S, Kalunde MS, Chandrasiri T, Towers GHN. 1996b. Leafswallowing by chimpanzees, a behavioral adaptation for the control of strongyle nematode infections. Int J Primatol 72:475-503

Huffman MA, Gotoh S, Turner L, Yoshida K. 1997. Seasonal trends in intestinal nematode infection and medicinal plant use among chimpanzees in the Mahale Mountains, Tanzania. Primates 38:111-125.

Huffman MA, Ohigashi H, Kawanaka M, Page, JE, Kirby GC, Gasquet M, Murakami A, Koshimizu K. 1998 a. African great ape self-medication: A new paradigm for treating parasite disease with natural medicines. In: Ebizuka,Y. Towards Natural Medicine Research in the 21st Century. Amsterdam: Elsevier Science BV, p 113-123.

Huffman MA, Elias R, Balansard G, Ohigashi H, Nansen P. 1998b. L'automédication chez les singes anthropoïdes : une étude multidisciplinaire sur le comportement, le régime alimentaire et la santé. Primatologie 1:179-204. 
Huffman MA, Caton JM. 2001. Self-induced increase of gut motility and the control of parasite infections in wild chimpanzees. Int J Primatol 22:329-346.

Jäger AK, Hutchings A, van Staden J. 1996. Screening of Zulu medicinal plants for prostaglandin-synthesis inhibitors. J Ethnopharmacol 52:95-100.

Janzen, D.H. 1978. Complications in interpreting the chemical defenses of trees against tropical arboreal planteating vertebrates. In. G.G. Montegomery (ed.): The Ecology of Arboreal Folivores. Washington, DC : Smithsonian Intitute Press, p 73-84.

Jisaka M, Ohigashi H, Takagaki T, Nozaki T, Tada T, Hirota M, Irie R, Huffman MA, Nishida T, Kajie M, Koshimizu K.1992. Bitter steroid glucosides, vernoniosides A1, A2 and A3, and related B1 from a possible medicinal plant, Vernonia amygdalina, used by wild chimpanzees. Tetrahedron 48:625-632.

Jisaka M, Ohigashi H, Takegawa K, Hirota M, Irie R, Huffman MA, Koshimizu K. 1993. Steroid glucosides from Vernonia amygdalina, a possible chimpanzee medicinal plant. Phytochemistry 34:409-413.

Koshimizu K, Ohigashi H, Huffman MA, Nishida T, Takasaki H. 1993. Physiological activities and the active constituents of potentially medicinal plants used by wild chimpanzees of the Mahale Mountains, Tanzania. Int J Primatol 14:345-356.

Koshimizu K, Ohigashi H, Huffman MA. 1994. Use of Vernonia amygdalina by wild chimpanzee : possible roles of its bitter and related constituents. Physiology \& Behavior 56:1209-1216.

Kuhe C, Williamson EM, Roberts MF, Watt R, Hazra B, Lajubutu BA, Yang SL. 1998. Antiinflammatory activity of binaphtoquinones from Diospyros species. Phytother Res 12:155-158.

Krief S.2003. Métabolites secondaires des plantes et comportement animal: surveillance sanitaire et observations de l'alimentation de chimpanzés (Pan troglodytes schweinfurthii) en Ouganda. Activités biologiques et étude chimique de plantes consommées. Thèse de Doctorat du Museum National d'Histoire Naturelle, Paris. 375 p.

Krief S, Bories C, Hladik C-M. 2003. Résultats des examens parasitologiques de selles pratiqués sur une population de chimpanzés sauvages (Pan troglodytes schweinfurthii) d'Ouganda. Bull Soc Pathol Exot 96:80-81.

Krief S, Martin M-T, Grellier P, Kasenene J, Sévenet T. 2004. Novel antimalarial compounds isolated after the survey of self-medicative behavior of wild chimpanzees in Uganda. Antimicrob Agents Chemother, 48:3196-3199.

Loiseau PM, Lubert P, Wolf JG. 2000. Contribution of dithiol ligands to the in vitro and in vivo trypanocidal activities of dithiarsanes and study of ligand exchange in aqueous solution. Antimicrob Agents Chemother 44:2954-2961.

Lozano GA. 1998. Parasitic stress and self-medication in wild animals. In: MØller PA, Milinski M, Slater PJB, editors. Adv Study Behav. London: Academic Press. 27:291-317.

Mbongo N, Loiseau PM, Lawrence F, Bories C, Craciunescu DG., Robert-Gero M. 1997. In vitro sensitivity of Leishmania donovani to organometallic derivates of pentamidine. Parasitol Res 83:515-517.

Messner EJ, Wrangham RW. 1996. In vitro testing of the biological activity of Rubia cordifolia leaves on primate Strongyloides species. Primates 37:105-108.

Norhamon AW, Hazra B. 1997. Inhibition of tumor promoter induced Epstein-Barr virus activation by Diospyrin, a plant-derived anti-tumour coumpound, and its synthetic derivates. Phytother Res 1:588590. 
Ohigashi H, Huffman MA, Izutsu D, Koshimizu K, Kawanaka M, Sugiyama H, Kirby GC, Warhust DC, Allen D, Delmas F, Elias R, Balansard G. 1994. Towards the chemical ecology of medicinal plantuse in chimpanzees : the case of Vernonia amygdalina, a plant used by wild chimpanzees possibly for parasite-related diseases. J Chem Ecol 20:541-553.

Pal S, Barnerjee A, Hazra B. 1996. Pharmacological studies on the effect of the treatment of Swiss A Mice with Diospyrin, a tumour-inhibitory plant product, and its synthetic derivates. Phytother Res 10:393397.

Prélude website. L $\square$ utilisation de quelques plantes en médecine traditionnelle et vétérinaire en Afrique subsaharienne. http://www.preludedb.be.tf

Rode KD, Chapman CA, Chapman LJ, and McDowell LR. 2003. Mineral resource availability and consumption by colobus in Kibale National Park, Uganda. Int J Primatol 24: 541-573.

Rodriguez E, Aregullin M, Nishida T, Uehara S, Wrangham R, Abramowski Z, Finlayson A and Towers GHN. 1985. Thiarubrine A, a bioactive constituent of Aspilia (Asteraceae) consumed by wild chimpanzees. Experientia 41:419-420.

Shoemaker RH, Abbot BJ, Macdonald MM, Mayo JG, Venditti JM, Wolpert-De Filippes MK. 1983. Use of the KB cell line for in vitro cytotoxicity assays. Cancer Treatment reports 67:97

Skinner MF, Dupras TL, Moya-Sola S. 1995. Periodicity of linear enamel hypoplasia among Miocene Dryopithecus from Spain. J. Paleopathol 7:195-222.

Skinner MF,Hopwood D. 2004. Hypothesis for the causes and periodicity of repetitive linear enamel hypoplasia in large wild African (Pan troglodytes and Gorilla gorilla) and Asian (Pongo pygmaeus) Apes. Am J Phys Anthropol 123:216-235.

Toft JD. 1986. The pathoparasitology of non-human primates: a review. In: Benirshke K, editor. Primates : the road to self-sustaining population, Springer-Verlag, New York. p 571-679.

Trager W, Jensen JB. 1976. Human malarial parasites in continuous culture. Science 193:673-675.

Vitazkova SK, Long E, Paul A, Glendinning JI. 2001. Mice suppress malaria infection by sampling a "bitter"chemotherapy agent. Anim Behav 61: 887-884.

Watt JM , Breyer-Brandwijk MG. 1962. Medicinal and poisonous plants of southern and eastern Africa. $2^{\text {nde }}$ edition. E\&S Livingstone LTD.

Wrangham RW, Goodall J. 1989. Chimpanzee use of medicinal leaves. In: Heltne PG, Marquardt LA, editors. Understanding Chimpanzees, Cambridge, MA: Harvard. p 22-37.

Wrangham RW. 1995. Leaf-swallowing by chimpanzees and its relationship to tapeworm infection. Am J Primatol 37:297-304.

Wrangham RW, Waterman PG. 1983. Condensed tannins in fruits eaten by chimpanzees. Biotropica 15:217222.

Wrangham RW, Nishida T. 1983. Aspilia spp. leaves: a puzzle in the feeding behavior of wild chimpanzees. Primates 24:276-282.

Wrangham RW, Conklin-Brittain NL, Hunt KD. 1998. Dietetary response of chimpanzees and Cercopithecines to seasonal variation in fruit abundance. I. Antifeedants. Int J Primatol 19:949-970.

Yardley V, Snowdon D, Croft S, Hazra B. 1996. In vitro activity of Diospyrin and derivates against Leishmania donovani, Trypanosoma cruzi and Trypanosoma brucei brucei. Phytother Res 10:559-562. 